\title{
Tahapan Pernikahan Masyarakat Di Kecamatan Donggo Kabupaten Bima
}

\author{
Darwis \\ Syukurman \\ Program Studi Pendidikan Sosiologi \\ Sekolah Tinggi Keguruan dan Ilmu Pengetahuan (STKIP) Bima \\ Email: darwis sos@stkipbima.ac.id \\ syukurmanstkip@gmail.com
}

\begin{abstract}
ABSTRAK
Indonesia sebagai salah satu negara yang memiliki kekayaan budaya yang beragam. Kekayaan tersebut tercermin dari pelaksanaan pernikahan. Kecamatan Donggo sebagai bagian dari Kabupaten Bima memiliki tahapan pernikahan yang beberapa hal berbeda dengan Kecamatan yang lain. Penelitian ini bertujuan untuk mencari tahu tentang sistem pelaksanaan pernikahan masyarakat Kecamatan Donggo. Adapun pendekatan dalam penelitian ini adalah kualitatif dengan jenis penelitian studi kasus. Waktu yang digunakan selama empat bulan. Tempat penelitian Kecamatan Donggo Kabupaten Bima, dengan subjek penelitian masyarakat Kecamatan Donggo yang mengetahui tentang tahapan pernikahan. Data dan sumber data berasal dari data primer dan data sekunder. Teknik pengumpulan data observasi, wawancara, dan dokumentasi. Teknik analisis: reduksi data, display data dan kesimpulan. Adapun hasil penelitian pelaksanaan pernikahan masyarakat Donggo meliputi dua tahapan. Pertama, pra pelaksanaan pernikahan Cepe kaneve, sodi ntaru, Wi'i ngahi, nge'e nuru, Cempe rima, rawi mbaju, mbolo weki, wa'a co'i, teka ra ne'e, kapanca, akad, dan jambuta. Tahapan-tahapan tersebut menentukan terlaksananya adat dalam pelaksanaan pernikahan masyarakat Donggo. Kemudian di lanjutkan dengan tahap kedua yaitu kegiatan adat pasca pelaksanaan pernikahan yaitu mboho oi mbaru, tio rana ngaha sahe bura dan tio rana atau Cama sebagai cara untuk menguji sikap baik, patuh seorang menantu kepada mertua. Adapun adat pernikahan dengan sistem londo Iha, dan kempa angi adalah pilihan yang diambil oleh pihak laki-laki atau perempuan jika diantara keluarga tidak menyetujui pernikahan mereka.
\end{abstract}

Kata kunci: Pernikahan, Masyarakat 


\section{PENDAHULUAN}

\section{Pengetian Pernikahan}

Pernikahan merupakan prosesi sakral dalam kehidupan manusia. UndangUndang Nomor 1 Tahun 1974 Pasal 1 menyatakan bahwa Pernikahan adalah ikatan lahir batin antara seorang pria dan seorang wanita sebagai suami istri dengan tujuan membentuk keluarga atau rumah tangga yang bahagia dan kekal berdasarkan Ketuhanan Yang Maha Esa. Pada Pasal 2 menyatakan bahwa Pernikahan dinyatakan sah apabila dilakukan menurut Hukum masing-masing Agama dan Kepercayaannya, serta tiap-tiap Pernikahan dicatat menurut Peraturan Perundang-Undangan yang berlaku. Selain dalam kegiatan kemasyarakatan, cara hidup komunal juga dapat dilihat dalam pernikahan. Hukum adat memandang bahwa Pernikahan adalah peristiwa yang mengandung unsur magis serta merupakan urusan seluruh masyarakat, bukan hanya ikatan kontraktual atau urusan mereka yang menjadi calon mempelai. Pernikahan merupakan suatu kejadian yang sangat penting dalam kehidupan seseorang karena ikatan perkawinan yang timbul antara seorang laki-laki dan perempuan menimbulkan hubungan lahiriah dan spritual (Rahman, Fahmi dan Nurmukminah, 2010)

Pernikahan merupakan perjanjian anntara seorang laki-laki dan seorang perempuan. Perjanjian ini bukan sembarang perjanjian jual beli atau sewa menyewa, tetapi perjanjian dalam pernikahan adalah perjanjian suci untuk membentuk keluarga antara keluarga laki-laki dan keluarga perempuan suci (Yasin, 2008). Sedangkan menurut Kompilasi Hukum Islam (KHI) tujuan perkawinan dijelaskan pada pasal $3 \mathrm{KHI}$ yaitu " Perkawinan bertujuan untuk mewujudkan rumah tangga sakinah, mawaddah dan wa rahmah. "Artinya tujuan perkawinan sesuai dengan konsep Hukum Islam. Perbedaan KHI dan UU Nomor 1 Tahun 1974 juga tampak pada penerapan sahnya perkawinan. Pasal 2 UU Nomor 1 Tahun 1974 menjelaskan "Perkawinan adalah sah, apabila dilakukan menurut hukum masing-masing agamanya dan kepercayaannya itu”. Artinya perkawinan yang dilakukan menurut hukum agama Islam, Kristen, Budha, Hindu adalah sah menurut UU Perkawinan.

Setiap masyarakat mempunyai sistem yang mengatur kehidupan dan interaksi anggotanya, salah satu interaksi dalam masyarakat adalah perkawinan. Menurut pada keluarga manusia perhubungan darah dan sex diubah menjadi perhubungan permanen yang mempunyai harga tersendiri, bukan hanya antara pasangan yang kawin, tetapi juga 
antara mereka dan anak mereka (Alisyahbana, 1986). Selain itu berpendapat bahwa perkawinan adalah saat peralihan yang pada semua masyarakat dianggap penting adalah peralihan dari tingkat hidup remaja ke tingakat hidup berkeluarga. Dalam kebudayaan manusia, perkawinan merupakan pengatur tingkah laku manusia yang berakitan dengan kehidupan kelaminnya. Selain sebagai pengatur kehidupan kelamin, perkawinan mempunyai berbagai fungsi dalam kehidupan bermasyarakat manusia, yaitu memberi perlindungan kepada anak-anak hasil perkawinannya itu, memenuhi kebutuhan manusia akan seorang teman hidup, memenuhi kebutuhan akan harta dan gengsi, tetapi juga untuk memelihara hubungan baik dengan kelompok-kelompok kerabat tertentu (Koentjaraningrat, 2002). Prosesi atau tahapan pernikahan bukan hanya terjadi begitu saja, tapi dilakukan dengan berbagai macam ritual dan perayaan. Setiap tahapan-tahapan dalam prosesi pernikahan sangat dipengaruhi oleh budaya dan adat-istiadat masyarakatnya. Artinya acara pernikahan adalah peristiwa sakral yang berkaitan dengan budaya dan agama.

Dari pendapat ahli tersebut dapat dikatakan bahwa perkawinan adalah suatu kontrak adat istiadat atau pertalian antara laki-laki dengan seorang perempuan yang dibatasi hak dan kewajibannya, melegitimasi status dan kekerabatan, menjembatani hubungan dengan individu dan kelompok yang lain. Dalam kehidupan manusia, banyak fase yang terjadi. Fase-fase tersebut bermulanya ditandai dengan dilakukannya upacaraupacara adat yang bertujuan agar seorang yang menjadi objek dari upacara tersebut bisa menjalani fase-fase hidup yang baru itu dengan baik dan selamat (Raba, et.al, 2002). Pernikahan (nika ra neku) dalam tradisi Bima memiliki aturan baku. Aturan itu cukup ketat sehingga satu kesalahan bisa membuat rencana pernikahan (nika) menjadi tertunda bahkan batal. Dulu, seorang calon mempelai laki-laki tidak diperkenankan berpapasan dengan calon mertua. Dia harus menghindari jalan berpapasan. Jika kebetulan berpapasan makan calon dianggap tidak sopan. Untuk itu harus dihukum dengan menolaknya menjadi menantu. Aturan yang ketat itu tentu menjadi bermakna karena ditaati oleh segenap anggota masyarakat. Kini, tentu saja aturan tersebut sudah ditinggalkan. Misalnya ngge'e nuru atau tinggal bersama calon mertua untuk mengabdi di sana. Dalam tradisi Bima, ada tahapan-tahapan yang harus dilalui oleh masyarakat Bima sebelum pernikahan yaitu (Rahman, Fahmi., \& Nurmukminah, 2010). 
Secara antropologi budaya masyarakat Bima adalah orang-orang yang dalam hidup kesehariannya menggunakan bahasa Bima dengan berbagai dialeknya secara turun temurun. Bima, Yang sekarang mencakup kota Bima dan Kabupaten Bima. Dulu bernama Mbojo dan hingga sekarang tetap populer di kalangan masyarakat dengan istilah Dana Mbojo, yang artinya Tanah Bima; Nggahi Mbojo yang artinya Bahasa Bima, Dou Mbojo yang artinya Orang Bima dan lain-lain. Menurut informasi dan cerita-cerita dari orang tua dan ahli adat Bima, kata Mbojo berasal dari kata Babuju, yaitu tanah yang rada menonjol dan/atau berbukit (bahasa Bima, Dana ma Buju) tempat bersemayam para raja-raja ketika di lantik dan disumpah yang letak di Dara (kini dekat makam pahlawan di Bima). (Amin, 1971). Daerah Bima, terdiri dari delapan belas kecamatan sebagai penduduk asli yang mendiami di daerah Bima, yakni salah satunya adalah masyarakat Donggo. Masyarakat Donggo dianggap sebagai orang pertama yang telah mendiami daerah Bima. Donggo di bagi dua yaitu Donggo Di (Donggo Barat), Donggo Di di sebut Mbawa yang terletak di sebalah barat teluk Bima atau di sebut Ipa (seberang) dan Dou Donggo Ele (Orang Donggo Timur) terbagi menjadi dua, Donggo Ele yaitu Wawo yang berada di sekitar gunung lambitu dan sudah di mekarkan menjadi kecamatan Lambitu Yang mendiami daerah dataran tinggi pegunungan di wilayah Bima Tengah dan Donggo Ese (Donggo atas) yaitu Wera, mendiami daerah dataran tinggi pegunungan di wilayah Bima utara.

Kehidupan bermasyarakat Donggo menggunakan Azas gotong Royong, segala aktifitas masayarakat Donggo dilakukan dengan kolektifitas (Gotong Royong), budaya rotong royong sudah mengakar menjadi nilai yang harus di pegang teguh dan juga sebagai pedoman hidup bermasyarakat (peran manusia sebagai mahluk sosial) di dalam kehidupan masyarakat Donggo. di dilaksanakan dengan semangat gotong goyong antar kerabat bahkan antar warga. Bentuk kegiatanya dapat dilihat melalui kegiatan seperti rawi mori dana rawi made. Kegiatan rawi made yaitu kegiatan masyarakat terhadap hajatan orang yang meninggl dunia sedangkan kegiatan rawi ori yaitu acara-acara adat kebiasaan masyarakat Donggo sebagai kebudayaan yang masih di lestarikan adalah salah satunya adat pernikahan.

Dengan memperhatikan penjelasan diatas maka yang menjadi rumusan masalah dalam penelitian ini adalah bagaimanakah tahapan-tahapan dalam pelaksanaan pernikahan Masyarakat Kecamatan Donggo?. Adapun manfaat yang diharapkan dari 
penelitian ini diharapkan dapat memberikan sumbangan bagi perkembangan ilmu pengetahuan dan menambah khasanah pengetahuan terutama bagi penulis dan masyarakat pada umumnya. Serta memperkenalkan tentang kekayaan budaya Indonesia lebih khususnya budaya Donggo agar terus dipilihara dan dijaga keasliannya.

\section{Tahapan Upacara Pernikahan Masyarakat Bima}

Masayarakat Bima khususnya masyarakat yang ada di Kecmatan Donggo memiliki beberapa tahapan dalam perayaan pernikahan hal itu sebagaimana yang yang dikatakan oleh Rahman, Fahmi., \& Nurmukminah (2010) yaitu;

\section{Tahapan Wi'i Ngahi atau Panati}

Sodi Ntaruna merupakan tahap pertama yang dilakukan untuk menanyakan apakah gadis yang didatangi oleh pihak laki-lak tersebut belum dilamar sama orang. Sekaligus menanyakan apakah keluarga gadis bersedia menerima anak dari pihak keluarga laki-laki untuk menjadi menantunya.

Panati atau Sodi Ntaruna diawali dengan datangnya utusan pihak laki-laki ke orang tua perempuan. Utusan datang untuk menanyakan apakah sang gadis sudah memiliki kumbang atau calon suami. Bila memperoleh jawaban bahwa sang perempuan berstatus bebas, kembali dilakukan pendekatan untuk mengetahui apakah perempuan itu dapat dilamar. Jika lamaran itu diterima oleh pihak perempuan, si pria melakukan apa yang disebut wi'i nggahi. Pada hari yang ditetapkan, pertunangan diresmikan dalam Upacara Pita Nggahi.

\section{Tahapan Dou Sodi}

Upacara melamar atau meminang dalam bahasa daerah disebut panati. Orang yang diutus untuk melakukan pinangan disebut Ompu Panati. Bila pinangan itu diterima, resmilah kedua remaja berada dalam ikatan pacaran. Satu dengan yang lain disebut dou sodi (dou artinya orang, sodi artinya tanya, maksudnya orang yang sudah ditanya isi hatinya dan sepakat untuk dinikahkan. Jika kedua remaja itu sudah mengikat janji, biasanya perempuan meminta sang pria agar mengirim orang tuanya. Biasanya sodi angi tidak berlangsung lama melainkan langsung diikuti dengan melamar sang gadis. Tujuannya, antara lain, untuk menghindari fitnah dan hal-hal lain yang tidak terpuji. 


\section{Tahapan Ngge'e Nuru}

Ngge'e nuru maksudnya calon suami tinggal bersama di rumah calon mertua. Ngge'e artinya tinggal, nuru artinya ikut. Pria sudah diterima lamarannya, bila kedua belah pihak menghendaki, sang pria diperkenankan tinggal bersama calon mertua di rumah calon mertua. Dia akan menanti bulan baik dan hari baik untuk melaksanakan upacara pernikahan. Datangnya sang pria untuk tinggal di rumah calon mertua inilah yang disebut dengan Ngge'e Nuru. Selama terjadinya ngge'e nuru, sang pria harus memperlihatkan sikap, tingkah laku dan tutur kata yang baik kepada calon mertuanya. Bila selama ngge'e nuru ini sang pria memperlihatkan sikap, tingkah laku dan tutur kata yang tidak sopan, malas dan sebagainya, atau tak pernah melakukan shalat, lamaran bisa dibatalkan secara sepihak oleh keluarga perempuan. Ini berarti ikatan sodi angi diantara dua remaja tadi putus.

Tujuan utama ngge'e nuru ini adalah proses adaptasi antara sang pria dengan kehidupan calom mertua. Selama ngge'e nuru, pria tidak diperkenankan bergaul bebas dengan perempuan calon istrinya.

\section{Tahapan Mbolo Weki}

Mbolo weki adalah upacara musyawarah dan mufakat seluruh keluarga maupun handai taulan dalam masyarakat untuk merundingkan segala sesuatu yang berhubungan dengan pelaksanaan hajatan/rencana perkawinan yang akan dilaksanakan. Dalam tradisi khitanan juga demikian. Hal-hal yang dimufakatkan dalam acara mbolo weki meliputi penentuan hari baik, bulan baik untuk melaksanakan hajatan tersebut serta pembagian tugas kepada keluarga dan handai taulan.

Bila ada hajatan pernikahan, masyarakat dengan sendirinya bergotong royong membantu keluarga melaksanakan hajatan. Bantuan berupa uang, hewan ternak, padi/beras dan lainnya.

\section{Tahapan Wa'a Coi}

Wa' a coi maksudnya adalah upacara menghantar mahar atau mas kawin, dari keluarga pria kepada keluarga sang gadis. Dengan adanya upacara ini, berarti beberapa hari lagi kedua remaja tadi akan segera dinikahkan. Banyaknya barang dan besarnya nilai mahar, tergantung hasil mufakat antara kedua orang tua remaja tersebut. Pada umumnya mahar berupa rumah, perabotan rumah tangga, perlengkapan tidur dan sebagainya. Tapi semuanya itu harus dijelaskan berapa nilai nominalnya. 
Upacara mengantar mahar ini biasanya dihadiri dan disaksikan oleh seluruh anggota masyarakat di sekitarnya. Digelar pula arak-arakan yang meriah dari rumah orang tua sang pria menuju rumah orang tua perempuan. Semua perlengkapan mahar dan kebutuhan lain untuk upacara pernikahan seperti beras, kayu api, hewan ternak, jajan dan sebagainya ikut dibawa.

\section{Tahapan Teka Ra Ne'e}

Teka ra ne'e ke keluarga yang melaksanakan hajatan merupakan kebiasaan di kalangan masyarakat Bima. Teka ra ne'e berupa pemberian bantuan pada keluarga yang mengawinkan putra putrinya. Bila upacara teka ra ne'e dimulai, berduyun-duyunlah masyarakat (umumnya kaum wanita) datang ke rumah keluarga tuan rumah membawa uang, bahan pakaian dan sebagainya. Selama acara pernikahan digelar keramaian seperti malam hadrah atau biola semalam suntuk. Ada pula olahraga seperti guntaw atau tarian seperti buja kadanda

\section{Tahapan Jambuta}

Ada sebuah acara yang menjadi bagian dari prosesi perkawinan yaitu jambuta. Semula acara ini hanya berlaku di kalangan etnis Arab, namun akhirnya menjadi bagian dari tradisi Bima maupun Orang Melayu. Jambuta hampir sama tujuannya dengan Teka ra ne'e namun pelaksanaannya cukup satu hari. Sedang Teka ra ne'e berkisar antara dua hingga tiga hari.

\section{Tahapan Kapanca}

Upacara ini dilaksanakan sehari sebelum calon penganti wanita dinikahkan. Setiba di uma ruka, calon pengantin wanita akan melaksanakan acara adat yang disebut kapanca, yaitu acara penempelan kapanca (inai) di atas telapak tangan calon pengantin wanita. Dilakukan secara bergiliran oleh ibu-ibu pemuka adat. Kapanca merupakan peringatan bagi si calon pengantin wanita bahwa dalam waktu yang tak lama lagi akan melakukan tugas sebagai istri atau ibu rumah tangga.

Seiring dengan kegiatan kapanca, akan disuguhkan juga sejenis kesenian rakyat yang bernafaskan ajaran Islam yang disebut Ziki Kapanca yang dilakukan oleh para undangan. Mereka akan membawakan syair bernuansa Islam yang liriknya berisi pujian dan sanjungan pada Allah dan Rasul. Usai Ziki Kapanca dilanjutkan dengan pertunjukan kesenian dan musik Mbojo Bima semalam suntuk. 


\section{Tahapan Akad Nikah}

Akad nikah merupakan puncak acara. Sebelum akad berlangsung, malamnya dilakukan upacara kapanca (memberi atau menghias daun pacar yang digiling halus pada jari-jari tangan dan kaki pengantin). Acara ini disebut londo dende, dimana pengantin pria diantar ramai-ramai oleh keluarga dan handai taulan dengan diiringi kesenian hadrah ke tempat pengantin wanita. Pengantin pria mengenakan pakaian adat pengantin. Kadang-kadang kedua pengantin diarak bersama-sama menuju tempat upacara. Seringkali pula hanya pengantin pria yang diarak. Pengantin wanita cukup menunggu di tempat upacara.

Di tempat pengantin wanita dipersiapkan berpakaian adat pengantin dan duduk di atas pelaminan yang dihias ornamen-ornamen tradisional. Duduknya di bawah (di atas kasur berhias) dengan bersimpuh menurut adat (doho tuku tatu'u). Ia didampingi seorang inang pengasuh dan dua remaja putri dari keluarga dekat yang bertugas mengipas, selain itu duduk pula dua orang laki-laki atau perempuan yang membawa alat penginang.

Di muka pelaminan duduk berbaris berhadap-hadapan putri-putri remaja yang membawa lilin berhias. Di belakang dan di samping mereka duduk para tamu ibu-ibu dan bapak-bapak. Orang tua pengantin wanita duduk di sebelah pelaminan. Ruangan tersebut dibatasi dengan tirai adat yang disebut Dindi Ra-Lara berwarna-warni. Biasanya dipakai warna merah, hijau, kuning dan putih. Saat pengantin dan rombongan naik atau masuk ke ruangan, mereka berhenti di depan tirai. Terjadilah semacam dialog pendek antara pengantar (bapak-bapak) pengantin pria dengan penjaga tirai (bapakbapak) pihak wanita. Setelah diserahkan uang pelumas dan sirih pinang, barulah tirai dibuka oleh ibu-ibu dari pihak wanita dari dalam tirai dan disambung dengan taburan beras kuning.

Masuklah pengantin pria dengan dikawal dua orang bapak atau ibu yang berhenti di depan pelaminan. Pengantin pria melangkah naik ke pelaminan dan menancapkan setangkai kembang ke atas gelung penganting wanita yang duduk membelakangi. Pengantin wanita mencabut kembangnya dan membuangnya (ini dilakukan tiga kali). Acara ini disebut nenggu. Setelah neggu, pengantin wanita berbalik dan sama-sama duduk berhadapan kemudian pengantin wanita sujud atau salaman 
dengan pengantin pria. Selanjutnya mereka duduk bersanding untuk disaksikan oleh undangan dan handai taulan.

Pada acara ini seluruh masyarakat, pemuka agama, laki prempuan diundang untuk menyaksikan dan memberi do'a restu. Pelaksanaan upacara ini bermacammacam. Kadang-kadang hanya dengan selamat biasa yang biasa disebut do'a jama. Kadang-kadang dengan pesta yang cukup meriah dengan diiringi orkes atau band. Dengan disaksikan oleh seluruh tamu, dihadapan petugas agama, saksi khusus, pengantin pria duduk berhadapan dengan calon mertuanya, berpegangan tangan dalam posisi dua ibu jari kanan mereka saling dirapatkan. Dalam posisi demikian, diadakanlah akad nikah atau ijab kabul yang dalam bahasa daerah disebut lafa. Akad nikah atau ijab kabul atau lafa harus didahului dengan mengucapkan kalimat syahadat yang diucapkan oleh calon mertua atau wali dengan diikuti oleh mempelai pria.

Selesai mengucapkan akad nikah, resmilah si pria menjadi suami si wanita. Proses selanjutnya adalah mengantar pengantin laki-laki menuju tempat duduk pengantin wanita dengan diantar oleh penghulu atau siapa saja yang ada di sekitar itu untuk melakukan upacara caka (jengkal) yaitu ibu jari kanan pengantin pria diletakkan di atas ubun-ubun pengantin wanita yang disusul dengan saling berjabat tangan antar kedua pengantin yang selanjutnya mereka duduk bersanding. Caka dimaksudkan sebagai pertanda permulaan sang suami menyentuh istrinya dan mulai saat itu mereka sudah halal untuk bergaul sebagai suami istri.

\section{Tahapan Boho Oi Ndeu}

Boho Oi Ndeu adalah mandi sebagai pertanda ucapan selamat tinggal atas masa remaja. Boho oi ndeu ini dilakukan sehari setelah akad nikah, dilangsungkan tapi sebelum pengantin bergaul sebagai suami istri. Pada upacara ini kedua pengantin duduk bersama pada tempat tertentu yang telah disediakan. Kemudian dari atas kepalanya oleh dukun dituangkan air yang sudah disiapkan dalam periuk tanah yang baru (roa bou; roa artinya periuk; bou berarti baru). Leher periuk dilingkari dengan segulung benang putih. Boho oi ndeu biasanya dilakukan pagi hari yang disusul dengan do'a selamatan pada sore harinya. Kedua pengantin duduk berdampingan, menduduki suatu alat tenun yang disebut lira, sedangkan badan mereka dililit dengan untaian benang tenun dari kapas putih sebagai lambang ikatan suci kemudian dilakukan siraman dengan air wangiwangian. Inilah akhir dari upacara nika ra neku. 
Acara mandi untuk calon pengantin wanita dilakukan juga sebelum upacara perkawinan, yakni pada pagi hari sebelum acara kapanca. Mandi ini disebut boho oi mbaru yang artinya memandikan atau menghapus masa kegadisan bagi calon pengantin wanita. Setelah mandi dilanjutkan dengan boru atau cukuran yaitu mencukur dahi calon mempelai wanita menurut bentuk dandanan yang diperlukan.

Pada hari ketiga, pengantin wanita diboyong ke rumah pengantin pria dalam acara yang disebut lao keka. Di tempat pengantin pria, diadakan acara pamaco, dimana kedua pengantin diperkenalkan pada para undangan yang satu per satu menyampaikan sumbangan, entah uang atau barang, bahkan secara simbolis menyerahkan seuntai tali apabila hadiahnya hanya merupakan seekor kerbau.

\section{METODE}

Adapun pendekatan dalam penelitian ini adalah deskritif kualitatif dengan jenis penelitian studi kasus. Waktu yang digunakan selama empat bulan. Tempat penelitian Kecamatan Donggo Kabupaten Bima, dengan subjek penelitian masyarakat Kecamatan Donggo yang mengetahui tentang tahapan pernikahan. Data dan sumber data berasal dari data primer dan data sekunder. Teknik pengumpulan data observasi, wawancara, dan dokumentasi. Teknik analisis data reduksi data, display data dan kesimpulan.

\section{HASIL DAN PEMBAHASAN}

Kecamatan Donggo dalam adminitrasi kepemerintahannya, merupakan bagian dari kabupaten Bima Propinsi NTB, berada di tengah wilayah kabupaten Bima. Luas wilayah Kecamatan Donggo mencapai $20.580 \mathrm{~km} 2$, terdiri dari sembilan desa, Dari sisi jarak ke pusat pemerintahan kecamatan, mencakup terdiri dari Desa Ndano Na'e dan Desa Bumi Pajo merupakan Desa yang berlokasi terjauh, dimana jarak masing-masing sekitar 46 km dan 48 km. Selanjutnya Desa Rora dan Desa Palama yang memiliki jarak cukup jauh dari pusat pemerintahan dengan jarak $40 \mathrm{~km}$ dan $42 \mathrm{~km}$, sedangkan Desa yang relatif dekat dengan pusat pemerintahan adalah Desa Mbawa $5 \mathrm{~km}$, Desa kala, Dori dungga masing-masing berjarak $3 \mathrm{~km}$. Desa yang paling dekat dengan pusat pemerintahan kecamatan Donggo seperti, Desa Mpili, dengan jarak 1,5 km dan Desa O'o sebagai pusat pemerintah kecamatan Donggo dengan jarak $1 \mathrm{~km}$. Kecamatan Donggo mempunyai ketinggian sekitar $650 \mathrm{mtr}$ di atas permukaan laut sehingga 
menjadikan Kecamatan ini sebagai kecamatan dengan lokasi ketinggian tertinggi di atas permukaan laut. dengan curah hujan $1350 \mathrm{Mm}$ dengan suhu rata-rata 25, $27 \mathrm{C}$,

Adat Masyarakat Donggo adalah masyarakat yang terbuka, masyarakat yang memiliki rasa solidaritas tinggi, serta saling bergantung antara satu dengan anggota masyarakat lainya dengan semangat sikap menghormati kepada orang tua sebaliknya orang tua menghargai yang kecil, demikian pula dalam aspek agama masyarakat Donggo memiliki sikap toleransi kehidupan antar bergama untuk bisa menerimaan perbedaan, entah itu perbedaan pendapat, maupun kepercayaan yang di anut, masingmasing melebur dan tunduk pada kebudayaan masyarakat.

Sistem nilai budaya, merupakan tingkat yang paling tinggi dan paling abstrak dari adat istiadat. Hal itu disebabkan karena nilai-nilai budaya itu merupakan konsepkonsep mengenai apa yang hidup dalam alam pikiran sebagian besar dari warga suatu masyarakat mengenai apa yang mereka anggap bernilai, berharga, dan penting dalam hidup, sehingga dapat berfungsi sebagai suatu pedoman yang memberi arah dan orientasi kepada kehidupan para warga masyarakat tersebut. Dalam tiap masyarakat, baik yang komplek maupun yang sederhana, ada sejumlah nilai budaya yang satu dengan lainnya berkaitan hingga merupakan satu sistem, dan sistem itu pedoman dari konsep-konsep ideal dalam kebudayaan dan memberi pendorong yang kuat terhadap arah kehidupan warga masyarakatnya.

Pernikahan adalah perilaku makhluk ciptaan Tuhan Yang Maha Esa, agar hidup didalam dunnia berkembang baik. Perkawinan bukan hanya terjadi dikalangan manusia tetapi juga pada tumbuhan dan hewan. Manusia adalah makhluk yang berakal dan perkawinan merupakan salah satu budaya beraturan yang mengikuti perkembangan manusia dalam kehidupan bermasyarakat. Perkawinan merupakan suatu hal yang sakral, dan sangat penting serta mulia untuk mengatur kehidupan rumah tangga dan masyarakat secara umum. Tanpa perkawinan tidak mungkin seorang laki-laki dan seorang perempuan dapat membentuk dan mengatur rumah tangga secara tertib dan teratur. Demikian pula tanpa adanya pengikat yakni perkawinan, tentulah anak yang dilahirkan tidak akan memiliki status yang jelas.

Dalam pembahasan ini pernikahan lebih diterjemahkan pada pengertian "kapan" seorang akan atau sudah boleh nikah. Dalam adat masyarakat Donggo tidak ditentukan secara tegas pada usia berapa seseorang sudah diperbolehkan untuk nikah. Sesuai 
kebiasaan jika seorang anak (baik laki-laki maupun perempuan) atau jika telah baligh atau dewasa (status cempe kanefe dan sodi ntaru) maka pihak orang tua memberikan semacam "batasan" dinamakan kahela wa'u dalam hal ini agar tidak terjadi hal-hal yang tidak di inginkan, memilih jodoh dengan harapan agar anaknya bisa bahagia setelah berumah tangga. Yang menjadi harapan orang tua biasanya calon menantunya yang berkelakuan baik, berbudi pekerti, rasa solidaritas yang tinggi, ramah dan sudah pasti dan beragama islam, karena basis kultural orang masyarakat Donggo adalah Islam kecuali di desa Mbawa dan desa Palama terdapat agama Kristen Protestan dan Kristen Khatolik, maka pelaksanaan upacara adat pernikahan selalu berpatokan pada adat istiadat masyarakat Donggo, kecuali yang berbeda adalah tempat pelaksanaan akad nikah, dari hal tersebut akan kembali mengacu pada sudut pandangan agama, Kristen Khatolik dan Protestan akan melaksanakan di gereja, itupun apabila penikahan suci, sedangkan bagi pasangan yang status Terjatuh (hamil di luar nikah) tidak di ijinkan melaksanakan akad nikahnya di dalam gereja (temapat suci) oleh Bapak gembala (pendeta), tetapi acara akad nikahnya di langsungkan di kampung atau di halaman rumahnya yang di saksikn oleh sara ro hukum, yang terdiri dari agama Islam dan Kristen, bahkan yang menjadi panati dilibatkan orang-orang bergama Islam juga.

Berdasarkan dalil diatas maka mahram dalam hal memilih jodoh orang tua di Donggo karena takut "membeli kuncing di dalam karung”, ada kebiasaan orang tua untuk mencarikan calon menantu dengan cara sodi nu'u, atau mencari tahu silsilah keluarga seperti halnya di lakukan orang tua di jawa mencari tahu kriteria seperti Bibit, Bobot, Bebet, begitupun tujuan orang Donggo melakukan sodi nu'u. yaitu proses yang di lakukan oleh masyarakat Donggo untuk mencari tahu silsilah keluarga perempuan yang ingin di jadikan calon menantu, sodi nu'u biasa di lakukan bagi pihak keluarga laki-laki dalam internal keluarga sebelum di lakukan cempe kanefe dan sodi ntaru.

Bentuk kriteria silsilah yang ingin di ketahui adalah pertama keturunan dari $N u$ 'u ina (saudara kandung ibu), Nu'u ana (keturunan dari anak), Nu'u amancawa (saudara perempuan dari Bapak). Adapun keluarga yang boleh di nikahi adalah keturunan dari $N u$ 'u ana dan $N u$ 'u amancawa, sedangkan dari keturunan $N u, u$ ina tidak boleh dinikahi, karena orang Donggo meyakini bahwa, apabila perempuan tersebut keturunan dari saudara ibu (nu'u ina) atau dalam istilah di Donggo ncao peke sanggere, 
perempuan didalam keturunan demikian tidak boleh di nikahi, karena di pahami sebagai weki ma deni (keluarga yang sangat dekat) bahkan di ibaratkan saudara kandung.

Masyarakat Donggo melakukan sodi angi sebagai cara untuk mencari tahu keturunan agar bisa menjamin apakah calon menantu mempunyai sikap yang baik dan patuh, cara ini menjadi kemestin yang di lakukan oleh masyarakat Donggo sekalipun calon menantu orang di luar Daerah Donggo, apabila hal ini tidak dilakukan mereka merasa kurang yakin terhadap calon menantunya tersebut, karena sering terjadi penyesalan orang tua di kemudian hari adanya peceraian anak mereka lantaran sebabnya tidak melakukan Sodi Nu'u dahulu.

Setiap masyarakat mempunyai sistem yang mengatur kehidupan dan interaksi anggotanya, salah satu interaksi dalam masyarakat adalah perkawinan. Menurut pada keluarga manusia perhubungan darah dan seks diubah menjadi perhubungan permanen yang mempunyai harga tersendiri, bukan hanya antara pasangan yang kawin, tetapi juga antara mereka dan anak mereka (Alisyahbana, 2007). Sistem pernikahan masyarakat Donggo dimana larangan-larangan yang terdapat turunan yang dekat ( $N u^{\prime} u$ Ina) Lebih lanjut bahwa system kekerabatan masyarakat Donggo berdasarkan hukum sanksi denda seperti Dua kali waru dan Piti Cepe Wei Dan Piti Rahi, yang diikuti dengan pola menetap Patri Lokal yaitu adat yang menetapkan calon istri dan calon suami pergi mengabdi di rumah calon mertua sebelum menikah, menurut adat masyarakat Donggo terdapat bentuk-bentuk pernikahan seperti: cepe kanefe, londo iha, kempa uma, sodi ntaru, cempe rima.

Prosesi perjanjian (wi'i nggahi) merupakan dasar terjadinya cepe kanefe ini karena kedua orang tua sepakat untuk menjodohkan anak-anak mereka atau pernikahan yang sudah dijodohkan sejak kecil. Antara kedua belah pihak sudah terdapat kata sepakat untuk menikahkan anak mereka setelah memasuki usia dewasa. Pernikahan ini dimaksudkan untuk mempererat tali persaudaraan. Sodi kanefe adalah perkawinan antar anak-anak dan bapak dan ibunya bersaudara dan karena kehendak orang tua, mereka dinikahkan.

Londo Iha adalah kedua belah pihak lari bersama-sama tanpa diketahui oleh kedua orang tua mereka. Kalau diperhatikan londo iha sebenarnya dipandang kurang baik dan tidak diinginkan oleh pihak keluarga si wanita maupun laki-laki sebagai alasan terjadinya londo iha antara lain disebabkan: 
Kempa Uma Pernikahan dengan cara menjebak dan di tangkap, model pernikahan ini biasa terjadi di Donggo, ada beberapa faktor sehingga dapat terjadi sebagai berikut. Pertama kempa uma apabila dikatahui atau ditemukan seseorang pemuda dengan seseorang perempuan ne'e angi( berpacaran) bercerita di rumah tampa penghuni yang lain atau di tempat yang tidak wajar, maka pemuda di akampung akan melapor kepada orang tua dan sara ro hukum terlebih dahulu sebelum di tangkap, maka akan segera mengawinkannya. Maksud dari perkawinan ini agar jangan sampai terjadi maksiat yang dapat menodai nama baik keluarga.

Kedua Kempa uma (menutup rumah) merupakan keinginan kedua orang tua dari kedua keluarga yang ingin menikahkan anaknya, awalnya orang tua perempuan akan menyuruh anak untuk membawa sesuatu di rumah keluarga sampela Mone (pemuda) ketika anak perempuannya tiba dirumah keluarga laki-laki, selanjutnya orang tua laki-laki pura-pura ada kesibukan di luar rumah agar anak mereka bisa tinggal berdua, selanjutnya kedua orang tua keluarga tersebut akan memberitahukan kepada sara ro hukum bahwa mereka ingin menjebak anaknya di rumah, agar secepatnya di nikahkan.

Ketiga kempa Uma misal ada sampela mone (pemuda) yang mencintai salah satu perempuan di kampungnya, dan memilki keinginan untuk menikahinya, Awalnya sampela mone (pemuda) akan memberitahukan kepada Sara Ro Hukum, di saat itulah direncanakan semuanya seperti waktu jebakan, jumlah peringatan jebakan, biasa tiga kali peringatan dari waktu di sepakati antara sara ro hukum dengan pemuda tersebut, sekalipun perempuan dengan keluarganya tidak mengetahui rencana pemuda tadi.

Sodi ntaru adalah istilah dalam bahasa Donggo untuk menyebut pernikahan lamaran (pinang). Sodi ntaru adalah system pernikahan yang umum di Donggo. Pernikahan ini terjadi apabila pihak keluarga laki-laki dan pihak keluarga perempuan telah terjadi hubungan cepe kanefe, atau tidak memilki status hubungan sebelumnya dan percintaan. Inisiatif melamar dari pihak kaum kerabat laki-laki dengan cara mengutus suatu delegasi (panati) kerumah orang tua perempuan untuk menanyakan perasaan anak perempuanya di namakan poda ngawana. Kunjungan lamaran ini disebut wi'i nggahi (perjanjian). Yang melamar biasanya saudara dari ayah laki-laki atau kerabat dekat dan sara ro hukum yang pandai merangkai dalam basa- basi yang mengandung kata-kata hikmah oleh panati disebut kapatu seperti. na mai podara 
nggahi mantantu ma poda wara. Na wa'aku ma sara, Na kacia ku ma hukum. Arti "pihak laki menunjukan besar rasa cinta dan kesungguhanya kepada perempuan yang ingin di lamar, dan pesan di bawa oleh panati dan keluarga, dan di perkuat oleh hukum" Apabila lamaran diterima oleh pihak perempuan di namakan wuja mama, maka pada saat itu terjadi persetujuan dan di tentukan mengenai waktu atau hari pernikahan dan belanja pernikahan yang diperlukan di namakan pita mama.

Cempe rima (pertukaran tenaga kerja) merupakan salah satu kegiatan seorang calon menantu baik laki-laki maupun perempuang pergi di tempatnya calon mertua untuk membantu setiap pekerjaannya. seperti kegiatan penting yaitu do'a keselamatan, resepsi, bahkan pekerjaan bercocok tanam di sawah, ladang, tujuan untuk menjaga hubungan baik agar terbentuknya keakraban didalam perjodohan, selain itu juga cempe rima sebagai tahapan menguji sikap, prilaku dan kemampuan melaksanakan tugas sebagai pasangan suami-istri dalam membina rumah tangga.

Mbolo Weki merupakan penentuan waktu karawi dalam upacara pernikahan menyangkut kerabat dari pihak laki-laki dan perempuan untuk ikut menentukan waktu, pembiayaan, dan pelkasnaan pernikhan yang menjadi tanggung jawab keluarga. Orang tua pihak laki-laki akan mengundang keluarga terdekat seperti saudara, nenek, serta kerabat lainya untuk Mbolo weki atau bermusyawarah membicarakan waktu dan segala perlengkapan pernikahan, dalam muswarah ini juga di bicarakan sekitar atau biaya yang di butuhkan yang bertujuan untuk menimbulkan partisipasi semua anggota kerabat bergotong royong memikul biaya. Mbolo weki akhirnya memutuskan pelaksanaan keputusan tersebut segera di sampaikan oleh ompu panti kepada keluarga gadis. Dengan adanya pemberitahuan tersebut maka keluarga pihak gadislah yang akan menentukan secara terpeinci mengenai hari dan tanggal pelaksanaanya. Keputusan oleh pihak keluarga perempuan sangat penting menyangkut persiapan pernikahan tersebut.

$W a$ 'a co'i adalah upacara pengantaran dan uang yang menjadi mas kawin dalam pernikahan. Biasanya sebelum mengantar belanja pernikahan di namakan rundu belanja. orang tua kedua belah pihak mengundang kerabat atau keluarga dekat dan pemuka masyarakat (sara ro hukum) untuk membicarakan waktu mulainya upacara antar belanja ( wa'a co'i) dapat saja terjadi bahwa waktu pelaksanaan pernikahan disepakati pada saat antar belanja (wa'a co'i), acara $W a$ 'a Co'i biasa pada pagi atau sore sangat bergantuk pada jauh dan dekatnya jarak, itu biasanya waktu mengantar mahar. 
Tahap-tahap semacam ini hanya dimulai oleh pihak laki-laki. Hal ini karena kedua keluarga berdasarkan kesepakatan antara keluarga dari kedua belah pihak.

Beberapa kelompok masyarakat Donggo masih mengharapkan upacara pernikahan yang meriah oleh karenanya kedudukan jumlah co' $i$ dengan beberapa sayarat pokok (lima ori) menjadi sangat penting dan tidak bisa dipisahkan dengan status sosial. Karena dalam kenyataannya sebagian besar dari co'i yang di serahkan pihak keluarga laki-laki kepada pihak keluarga perempuan di gunakan untuk biaya pesta pernikahan, maka akan terlihat adanya perbedaan maskawin atau mahar dengan ketentuan islam. Oleh karena itu co’ $i$ menurut masyarakat Donggo adalah maskawin "Dendi Siwi Kai Dou Siwe, Coi Ededu Dendi Ufa Kai Iha Sarumbuna" artinya untuk membujuk si gadis, maskawin sebagai hadiah rusak tubuhnya, yang di tambah dengan biaya-biaya dalam upacara pernikahan, dikarenakan menurut pemahamn masyarakat Donggo co' $i$ adalah ketentuan adat, maka besarnya juga di tentukan oleh pihak keluarga perempuan, sekalipun kemungkinan perundingan dengan pihak perempuan tetap ada. Dalam hal ini ompu panati dari keluarga laki-laki akan membicarakan secara kekeluargaan dengan pihak keluarga perempuan, dan calon mempelai tidak boleh ikut campur dalam penentuan. Sedangkan maskawin atau mahar menurut ketentuan hukum islam adalah hubungan antara calon suami dengan istri. Lebih lanjut lagi masyarakat Donggo ada kecendrungan mengikuti adat yang berlaku dan pola hidup yang agak Material.

Misalnya fungsi ekonomi keluarga, dalam keluarga terdapat pembagian kerja yang disesuaikan dengan status, peranan, jenis kelamin, dan umur anggota-anggota keluarga. Ayah sebagai kepala rumah tangga fungsional terhadap istri dan anakanaknya. Bagi keluarga pada umumnya ayah mempunyai peranan dan tanggung jawab utama dalam pemenuhan kebutuhan material para anggota keluarganya, meskipun para anggota keluarga lain (ibu dan anak-anak sudah dewasa) juga bekerja Robert K.Merton (Ritzer, 2009: 22)

Teka ra ne'e merupakan pemberian bantuan seperti Sapucu Bongi (satu baskom beras) atau uang, bahan pakaian dan sebagainya, Masyarakat berbondong-bondong (umumnya kaum wanita) dengan mendatangi rumah keluarga yang punya hajatan pernikahan. Kegiatan tersebut menjadi kebiasaan dan membudaya di kalangan masyarakat Donggo. Kegiatan teka ra ne'e biasa di lakukan pada pagi hari. 
Sifat kepedulian untuk saling membantu "peran manusia sebagai mahluk sosial"masyarakat khususnya Donggo dalam adat Teka Ra Nee dan upacara pernikahan akan terus berjalan sampai waktu yang tak dapat di ramalkan, sifat kegotong-royongan yang nampak dengan jelas didalam masyarakat Donggo patut di contohi, demikian pula semangat musyawarah dengan sikap saling menghargai didalam kehidupan kekeluargaan dan bermasyarakat merupakan inti dalam kehidupan masyarakat Donggo.

Adanya semangat solidaritas dan rasa sepenanggungan yang sama tertanam dalam setiap aktifitas masyarakat Donggo untuk memikul bersama yang menjadi tanggung jawab salah satu keluarga yang mempunyai hajatan pernikahan, beban keluarga tersebut dimudahkan dengan adanya bangunan kelompok masyarakat yang utuh seperti keterlibatan kerabat dekat, sara ro hukum, sehingga dapat memudahkan jalan dan suksesnya prosesi pernikahan

Sebagaimana para penganut teori struktural fungsional melihat masyarakat dengan menganalogikan masyarakat ibarat organisme biologis. Makhluk hidup yang bisa sehat atau sakit. Ia sehat jika bagian-bagian dari dirinya (kelompok/individu fungsional) memiliki kebersamaan satu sama lain. Jika ada bagiannya yang tidak lagi menyatu secara kolektif, maka kesehatan dari masyarakat tersebut terancam, atau sakit. Demikian halnya juga dalam keluarga yang terdiri dari anggota-anggota keluarga yang saling berhubungan satu sama lain dan fungsional terhadap anggota keluarga lainnya. Bahwa pada umumnya, keluarga terdiri dari ayah, ibu dan anak dimana masing-masing anggota keluarga tersebut saling mempengaruhi, saling membutuhkan, semua mengembangkan hubungan intensif antar anggota keluarga.

Upacara akad nikah, harus sesuai waktu yang baik yang tidak dihitung berdasarkan primbon Jawa. Biasanya acaranya dipagi hari. Walau akad nikah adalah sah secara hukum tetapi dalam kenyataannya masih banyak perhatian orang terpusat pada upacara temu yang terkadang menganggap sebagai bagian terpenting hari perayaan perkawinan. Padahal sebetulya peristiwa terpenting bagi calon pengantin adalah saat pemasangan cincin kawin yang setelah itu penghulu menyatakan bahwa mereka sah sebagai suami istri. Ijab adalah hal paling penting untuk melegalisir sebuah perkawinan. Ijab atau perkawinan dilaksanakan sesuai dengan agama yang dianut kedua pengantin, Islam, Kristen, Katolik, Hindu, Budha, Konghucu. Perkawinan diakui sah oleh Negara sesuai dengan Undang-Undang Republik Indonesia Nomor 23 Tahun 2006 tentang 
Administrasi Kependudukan dan Peraturan Pemerintah Republik Indonesia Nomor 37 Tahun 2007 Tentang Pelaksanaan Undang-Undang Nomor 23 Tahun 2006 tentang pernikahan.

Didalam pelaksanaan pernikahan di Donggo menunjukan terjadi perubahan kecendrungan tempat pelaksanaan Akad Nikah, yang sebelum sering di laksanakan dirumah keluarga mempelai, tetapi disaat sekarang sudah jarang terjadi, berarti menandakan sebagian kelompok masyarakat tertentu di Donggo bisa menerima setiap perubahan yang terjadi di lingkungan sosialnya, sekalipun ada sebagian kecil kelompok masih mengikuti adat istiadat ketimbang hukum positif (UU Pernikahan).

Setiap prosesi apa saja pasti memiliki tujuan tertentu Salah satu kegiatan resepsi pernikahan, bagi masyarakat Donggo upacara resepsi pernikahan selain acara ramah tamah, tetapi yang menjadi intinya adalah dalam rangka memberikan do'a dan ucapan selamat bagi pasangan pengantin dalam hal ini resepsi merupakan upacara setelah kedua pengantin tiba di barugak dihadapan tamu undangan, biasanya kegiatan resepsi di lakukan pada sore hari. Dan prosesi upacara resepsi diawalai dari keluarga pengantin pria, kemudian dipersilahkan bagi kaum wanita untuk memberikan sumbangan uang, atau barang (kado), para undangan laki-laki menyusul memberikan sumbangan dan sesudah semua tamu undangan memberikan salam kepada pengantin. Tamu undangan di suruh duduk kembali pada tempatnya sembari menikmati hidangan yang telah di sediakan. Tujuan dilaksanakanya resepsi pernikahan bertujuan meminta Do'a restu para anggota masyarakat, kerabat, teman. Dan kenalan juga untuk memberikan sumbangan berupa uang dan barang oleh tamu undangan.

Begitupun halnya adat ritual Masyarakat Donggo kaitan ritual adat cepe iri dan Ngaha Sahe Bura, Cepe iri Awalnya kedua orang tua mempelai akan menyuguhkan makanan dua ekor ayam jantan dan betina yang sudah di bakar, di tempatkan pada satu wadah (Nyiru) untuk kedua mempelai. tujuanya meminta do'a keselamatan agar di berikan rejeki keturunan bagi kedua mempelai.yang di lakukan dan di percayai masyarakat Donggo,

Ngaha Sahe Bura merupakan acara makan-makan kedua mempelai setelah resepsi usai, sebagai penyediaan pemenuhan kebutuhan awal makanan kesukaan mempelai perempuan, agar kedepan di saat mempelai perempuan ngidam tidak lagi meminta yang macam-macam makanan dalam jumlah banyak dan juga hakikatnya agar 
di karuniai keturunan. Ngaha sahe bura di laksanakan pada malam hari seperti halnya cepe iri. Tetapi ngaha sahe bura hanya organ penting saja yang di makan, ngaha sahe bura istilah yang di gunakan oleh masyarakat Desa Mbawa kecamatan Donggo

Terlepas beda istilahnya dan syarat tetapi tidak merubah sisi tujuan dan makna yang terkandung didalam pelaksanaanya, didalam ritual adat cepe iri atau ngaha sahe bura di lakukan dalam rangka sebagai upaya dan cara yang tepat bagi pasangan suami istri yang baru menikah agar bisa melahirkan anak dan menjaga keturunanya dari kelainan jiwa (rohani) dan cacat fisik (jasmani), dengan adanya beragam syarat yang harus di penuhi, lebih lanjut penulis menyimpulkan masyarakat Donggo adalah anggota masyarakat yang masih menjaga kelestarian ritual-ritual adat tertentu, teguhnya pemahaman terhadap kepercayaan dalam aspek syarat-syarat ritual adat cepe iri atau ngaha sahe bura terkandung makna memiliki korelasi dengan agama. Ritual adat cepe iri atau ngaha sahe bura adalah salah satu keaslian budaya upacara pasca pernikahan masyarakat Donggo yang tidak terdapat di kecamatan lain di Bima

Masyarakat Donggo juga melakukan ritual pemandian di namakan Boho oi mbaru adalah ritual pemandian air kelapa yang di tumpahkan di atas kepala pasangan duduk berdampingan tujuanya untuk melepaskan masa remaja, syarat-syarat, di ikat dengan kafan putih tujuh kali putaran, kepala pria dan wanita di tutupi dengan kain putih, pria dan wanita duduk di atas lihu, ketika di mandikan oleh ina bunti. agar kedua pasangan yang menikah tersebut tidak lagi mengingat masa-masa di mana mereka remaja, tentu sekian pengalaman (buruk) di waktu remaja akan di matangkan melalui ritual adat boho oi mbaru, di karenakan mereka akan menghadapi tantangan hidup yang lebih berat sebagi pasangan suami istri dalam menjalani rumah tangga.

Teori Interaksionis Simbolik. Menurut Herbert Blumer (1962) seorang tokoh modern dari Teori Interaksionisme Simbolik dalam Ritzer (2009:52) mengungkapkan bahwa istilah interaksionisme simbolik menunjuk kepada sifat khas dari interaksi antar manusia. Kekhasannya adalah manusia saling menerjemahkan dan saling mendefinisikan tindakannya. Tanggapan seseorang tidak dibuat secara langsung terhadap tindakan orang lain, melainkan didasarkan pada "makna" yang diberikan terhadap tindakan orang lain itu. Interaksi antara individu diantarai oleh penggunaan simbol-simbol, interpretasi atau dengan saling berusaha untuk saling memahami maksud dari tindakan masing-masing. 
Masyarakat Donggo memilki kebiasaan ritual adat merupakan kegiatan kunjungan menantu di rumah mertua, sekalipun terdapat istilah yang berbeda di desa Mbawa tetapi didalam pelaksanaan kegiatan Tio Rana Atau Cama terdapat inti sari yang sama yaitu, untuk mengetahui sikap menantu, memperkenalkan diri kepada anggota keluarga dan pemberian penghormatan yang simbolis seperti kue khas Donggo Kalempe dan Tembe Nggoli (sarung khas Bima) yang wajib harus di bawa oleh menantu perempuan kepada mertua, selain itu penulis melihat dari beberapa syarat yang harus di tanggung oleh keluarga perempuan lebih banyak dan beban besar karena keluarga perempuan menggunakan anggaran sendiri di luar dari mahar, untuk membuat kalempe dan untuk membeli sarung, lanjut dari itu kegiatan tio rana atau Cama adalah sesuatu yang wajib bagi pihak keluarga perempuan, sedangkan pihak keluarga laki-laki sifatnya tidak mengikat. Berarti masyarakat Donggo dapat di katakan sebagai masyarakat yang patriarki yaitu di mana perempuan selalu manjadi korban.

Bagaimana suatu budaya mengorganisasikan dirinya dan lembaganya mempengaruhi bagaimana anggota budaya mempersepsi dunia dan bagaimana mereka berkomunikasi. Terdapat dua unit sosial yang dominan sebagai lembaga Adat Donggo dalam mengatur suatu budaya masyarakat. Dan keluarga merupakan organisasi sosial terkecil dalam suatu budaya yang berpengaruh penting mengatur kehidupan bermasyarakat untuk menentukan aturan adat. Keberdaan lembaga Adat Sari'ah Masyarakat Donggo (LASDO) merupakan lembaga yang menjalankan aturan adat seperti yang berkenaan dengan mencuri, jinah, rujuk dan sebagainya masalah yang ada didalam kehidupan masyarakat Donggo, (LASDO) dengan struktur majelis adat yang tersebar di setiap desa di Donggo, kaum tua dan keterlibatan kaum pemuda yang masih progresif oleh karena sebagianya besar dari kalangan terpelajar, menarik sekali adanya persatuan pemahaman pendapat antara golongan tua dan muda, menjadikan lembaga adat sangat signinfikan perannya dalam menjalan aturan dan masyarakat sadar akan adanya lembaga tersebut cenderung masyarakat patuh terhadap aturan tersebut dengan melibatkan lembaga adat sebagai media persuasif yang membijaki segala persoalan, salah satunya kasus perjodohan dan penyelesaian berujung solusi hingga integrasi masyarak sangat solid.

Bahwa dengan danya aturan adat seperti denda piti cepe wei /rahi dan denda dua kali waru (denda 2x8) di jadikan regulasi permanen yang harus di ikuti dan 
pedoman bagi masyarakat Donggo, sifat aturan yang elastis, luwes tetapi berlaku khusus untuk mengatur tentang perjodohan yang menolak untuk menikah maupun keinginan cepat menikah, seorang induvidu yang melanggar kententuan aturan adat yang belaku alamiah yang tidak membutuhkan penegasan lanjutan dari orang lain untuk di patuhi, tetapi tinggal menjalankan aturan tersebut, hanya saja besaran sanksi yang akan di bahas pada rapat musyawarah antara kedua belah pihak keluarga dengan di mediasi oleh sara ro hukum. Obyektifitas aturan menggambarkan sasaran aturan yang berlaku egaliter yaitu"persamaan derajat" dapat menyeimbangkan aktifitas individu untuk mempertanggungjawabkan setiap pilihan "rasional maupun irasional, dengan artian sadar adanya aturan adat, tetapi masih melanggar" di dalam kehidupan bermasyarakat Donggo.

Setiap perkembangan jaman memiliki dampak perubahan bagi kehidupan kebudayaan masyarakat, asimilasi dan akultularasi, perkembangan ilmu pengetahuan dapat mengancam kelestarian kebudayaan daerah tertentu, begitupun kebudayaan dan adat istiadat pernikahan masyarakat Donggo sejak duhulu budaya tersebut menjadi langkah tepat untuk menjalin hubungan kekerabatan bagi setiap warga Donggo, tetapi dengan seiring di jaman yang serba canggih, sebagian sistem yang berlaku didalam tahapan pernikahan mengalami perubahan seperti syarat-syarat dan tata cara pelaksanaan bahkan sebagianya hampir punah di tengah kehidupan masyarakat Donggo.

Sistem pelaksanaan pernikahan masyarakat Donggo mengalami perubahan, disebabkan perasaan takut masyarakat di jaman sekarang untuk mengulangi kebiasaan masyarakat dahulu melakukan cempe kanefe, karena mengalami "perubahan fungsi", yang dahulunya sebagai perekat hubungan antara keluarga, tetapi justru sekarang lebih banyak menyisahkan konflik antara kedua keluarga tersebut sehingga menyebabkan kesenjangan sosial. Peneliti melihat faktor yang mendasar sebagai penghambat kelestarian prosesi cepe kanefe yaitu di sebabkan oleh terjadi pergeseran antara sistem itu sendiri yaitu cepe kanefe dengan sistem Denda piti cepe wei, piti cepe rahi. Pergeseran tersebut menyebabkan masyarakat Donggo ketakutan psikologis dan kerugian ekonomi serta sanksi sosial (moral) yang ditanggung oleh keluarga bersangkutan.

\section{KESIMPULAN}


Sebagai kesimpulan dari penelitian ini bahwa Masyarakat di Kecamatan Donggo dalam melaksanakan proses pernikahan secara garis besar dilakukan dengan dua tahapan. Pertama, pra pelaksanaan pernikahan Cepe kaneve (tukar pakaian bayi sebagai simbol bahwa anak mereka sudah dijodohkan), sodi ntaru adalah ketika orang tua lakilaki mengutus tokoh masyarakat dan adat mendatangi pihak keluarga perempuan menanyakan apakah anaknya tidak ada yang melamar. Sodi ntaru dilakukan apabila sebelumnya laki-laki yang menyukai pihak perempuan yang sebelumnya tidak melakukan prosesi cempe kaneve. Kemudian pita mama, Wi'i ngahi adalah prosesi ketika pihak keluarga laki-laki dan perempuan menyepakati perjodohan. Selanjutnya nge'e nuru adalah laki-laki membuktikan keseriusannya pada calon istrinya dengan tinggal atau berkerja bertahun-tahun dirumah, ladang pihak keluarga wanita. Cempe rima adalah pihak laki-laki berkerja dirumah atau ladang keluarga wanita dan pihak keluarga wanita berkerja di ladang, sawah pihak keluarga laki-laki. Cempe rima yang biasa dilakukan oleh wanita seperti menanam padi (nguda ndiha) sedangkan yang lakilaki membersihkan ladang yang sering masyarakat Donggo istilahkan ngoho ndiha (membersihkan ladang orang tua perempuan dengan melibatkan keluarga besar). Kemudian rawi mbaju adalah tahapan dimana semua masyarakat harus membawa satu ember padi ke keluarga pihak laki-laki dan perempuan sebagai bentuk gotong royong. Setelah rawi mbaju kemudian dilanjutkan dengan tahapan mbolo weki. Mbolo weki adalah tahapan dimana didalamnya keluarga dan masyarakat membicarakan tanggal jumlah mahar yang harus disiapkan oleh pihak keluarga laki-laki dan tanggal pernikahan sembari memberikan sumbangan seikhlasnya berupa uang kepada keluarga yang berhajat. Setelah prosesi mbolo weki maka, dilanjutkan dengan wa'a co'i atau menyerahkan mahar. sedangkan teka ra ne'e adalah kegiatan dimana masyarakat memberikan sejumlah beras kepada keluarga yang berhajat. Setelah tahapan teka ra ne'e dilanjutkan dengan tahapan kapanca atau prosesi merias pengantin perempuan biasanya kapanca dilakukan malam satu hari sebelum dilaksanakan prosesi akad nikah. Kemuadian tahap akhir yaitu akad, setelah selesai akad dilanjutkan dengan jambuta atau pesta pernikahan.

Tahapan kedua, yaitu kegiatan adat pasca pelaksanaan pernikahan yaitu mboho oi mbaru. Mboho oi mbaru adalah ritual mandi untuk Ritual Mboho oi mbaru adalah ritual yang dilakukan dimalam hari sesudah pesta pernihan. Kemudian setelah beberapa 
minggu atau bulan pihak kelurga perempuan akan melakukan prosesi tio Rana" (silaturahim mertua perempuan), tahapan ini dilakukan oleh penganten wanita dengan tujuan menambah erat dengan hubungannya, baik antara kedua penganten maupun maupun kedua orang tua penganten laki-laki dan perempuan, dengan membawa berbagai Jajan Tradisional dan Cinderamata sperti Kue, Kalempe, Kapore, Lawatu, kain sarung khas Donggo dan sebagainya.

\section{DAFTAR PUSTAKA}

Alisyahbana, S. Takdir. (1986). Antropologi Baru. Jakarta: PT. Rineka Cipta.

Amin, Ahmad. (1971). Sejarah Bima, Sejarah Pemerintahan dan Serba Serbi Kebudayaan Bima.

Koentjaraningrat. (2000). Kebudayaan Sebuah Mentalitas dan Pembangunan. Jakarta: PT. Gramedia Pustaka Utama.

Raba, Manggaukang, et.al. (2002). Fakta-Fakta tentang NTB, Lombok dan Sumbawa. Mataram: Yayasan Pembangunan Insan Citra.

Rahman, Fahmi., \& Nurmukminah. 2010. Nika Mbojo. Antara Islam dan Tradisi. Mataram: Alam Tara Learning Institut.

Ritzer, George. 2003. Sosiologi Ilmu Pengetahuan Berparadigma Ganda. Jakarta: PT. Raja Grafindo Persada.

Soekanto, Soejono. 2005. Sosiologi Suatu Pengantar. Jakarta: PT. Raja Grafindo

Yasin, Nur. 2008. Hukum Perkawinan Islam Sasak. UIN Malang. 